\title{
Investigation of Differences in the Cultivation of Nannochloropsis and Chlorella species by Fourier-transform Infrared Spectroscopy
}

\author{
Bernadett Kiss ${ }^{1}$, Szilveszter Gergely ${ }^{1}$ András Salgó1, Áron Németh ${ }^{1 *}$ \\ ${ }^{1}$ Department of Applied Biotechnology and Food Science, Faculty of Chemical Technology and Biotechnology, \\ Budapest University of Technology and Economics, H-1111 Budapest, Műegyetem rkp. 3, Hungary \\ * Corresponding author, e-mail: naron@f-labor.mkt.bme.hu
}

Received: 15 July 2018, Accepted: 08 October 2018, Published online: 20 November 2018

\begin{abstract}
The increasing use of energy in the world is leading to the exhaustion of fossil fuels, so novel alternative solutions have to be found to meet our needs. One solution is renewable raw materials extracted from algae. The use of microalgae is widespread, in addition to energy formation, their biomass can also be utilized as food and other valuable components of them, e.g. amino acids, vitamins and minerals can be used in drugs and cosmetics. Due to their boundless diversity and components, they have become the focus of an ever-increasing number of research areas. Different processes can induce changes in their nutritional content, so optimizing the conditions used during their cultivation is important to produce the desired product. In our study different isolates of microalgae, namely Nannochloropsis sp. and Chlorella vulgaris, were studied using Fourier-transform infrared (FT-IR) spectroscopic analysis. Variations in the spectra of a given species were studied under different cultivation conditions.
\end{abstract}

Keywords

Chlorella, Nannochloropsis, algae, FT-IR

\section{Introduction}

The applications of microalgae are spreading. Technological developments may result in the applications of algae becoming more economical in many fields, from bioenergetics to uses in the food industry. Their oil content, which could be used to produce biodiesel, has resulted in them becoming the focus of much research. Microalgae-based carbohydrates consist mainly of cellulose and lignin-free starch, thus providing carbon sources with fermentation for industry [1-7].

Besides the fuel industry, certain microalgae such as Nannochloropsis, Tetraselmis, Isochrysis, Thalassiosira and Chaetoceros are valuable nutritional supplements. Their long-chain fatty acid content, e.g. docosahexaenoic acid (DHA) and eicosapentaenoic acid (EPA), makes them important in the diet of humans. Algae are sources of functional food in the healthy diets of humans because they contain sterols, polyunsaturated fatty acids (PUFAs) and other functional ingredients [1-12].

Biomass from algae is also used in the treatment of ulcers and in cosmetics [13-14]. Their composition of bioactive substances makes them suitable in the production of medicines [15-19]. Preparations of microalgae are also used in agriculture for nutrition and leaf fertilization [1, 20-21]. Their carotenoid content, namely zeaxanthin, astaxanthin, canthaxanthin and lutein, has a beneficial effect of stimulating many repair and defense mechanisms in the human body to protect, for example, eyesight [16, 22-27]. Their composition also consists of many essential amino acids that the human body needs $[28,22]$.

The production of products intended for human consumption requires much more stringently controlled conditions, so they are produced in closed reactors. When producing biofuels, this is unnecessary, so open pond cultivation is also appropriate $[1,26,29-30]$.

The monitoring of algae cultivation is has several aspects. The best methods are capable of obtaining information not only about cell concentration, but even about changes in the intracellular composition of cells. One of the most current methods is to use the non-destructive techniques of Raman and IR spectroscopy, because of their insensitivity to the disturbing water signal, generally present on other IR spectra [31]. However, little 
information is available on Universal Attenuated Total Reflection (UATR)-based IR measurements for the cultivation of algae in the literature. Therefore we decided to examine the applicability of an FT-IR (UATR) equipment beside application of different strains, cultivation technics, aeration and carbon dioxide supplementation. These results provide basic data for the future monitoring of biomass, namely its amount and composition, even online during cultivation.

\section{Materials and Methods}

\subsection{Strains}

Nannochloropsis and Chlorella green algae species, which can be classified as eukaryotic microalgae, were investigated. Two isolates of Chlorella vulgaris, one from Tihany (T) and the other from Hamburg $(\mathrm{H})$, were examined.

\subsection{Media}

For spectroscopy investigations Nannochloropsis was cultured on the medium f/2 [26] and Chlorella was cultured on the medium BG-11 [32]. For comparative fermentation, inocula were grown in 200-200 $\mathrm{ml}$ of the corresponding media. The fermentation was conducted in a total volume of $700 \mathrm{~mL}$. The $\mathrm{f} / 2$ medium contained $1-1 \mathrm{~mL}$ of $75 \mathrm{gL}^{-1} \mathrm{NaNO}_{3}, 5 \mathrm{gL}^{-1} \mathrm{NaH}_{2} \mathrm{PO}_{4} \cdot \mathrm{H}_{2} \mathrm{O}$ and $0.5 \mathrm{ml}$ of both trace and vitamin solutions. The trace solution contained $3.15 \mathrm{~g}$ of $\mathrm{Fe}_{2} \mathrm{Cl}_{3} \cdot 6 \mathrm{H}_{2} \mathrm{O}, 4.36 \mathrm{~g}$ of $\mathrm{Na}_{2}$ EDTA. $\mathrm{H}_{2} \mathrm{O}$ as well as $1-1 \mathrm{~mL}$ of $9.8 \mathrm{gL}^{-1} \mathrm{CuSO}_{4} \cdot 5 \mathrm{H}_{2} \mathrm{O}, 6.3 \mathrm{gL}^{-1} \mathrm{Na}_{2} \mathrm{MoO}_{4} \cdot 2 \mathrm{H}_{2} \mathrm{O}$, $22.0 \mathrm{gL}^{-1} \mathrm{ZnSO}_{4} \cdot 7 \mathrm{H}_{2} \mathrm{O}, 10.0 \mathrm{gL}^{-1} \mathrm{CoCl}_{2} \cdot 6 \mathrm{H}_{2} \mathrm{O}$ and $180.0 \mathrm{gL}^{-1}$ $\mathrm{MnCl}_{2} \cdot \mathrm{H}_{2} \mathrm{O}$ solutions per liter. $1 \mathrm{~L}$ of vitamin solution contained $200 \mathrm{mg}$ of thiamine, $10 \mathrm{ml}$ of $0.1 \mathrm{gL}^{-1}$ biotin and $1 \mathrm{~mL}$ of $1.0 \mathrm{gL}^{-1}$ cobalamin. The medium BG-11 contained $1.5 \mathrm{~g}$ $\mathrm{NaNO}_{3}, 1 \mathrm{mg} \mathrm{Na} \mathrm{MgEDTA}, 66 \mathrm{mg} \mathrm{Fe}\left(\mathrm{NH}_{4}\right)_{2}\left(\mathrm{SO}_{4}\right)_{2} \cdot 6 \mathrm{H}_{2} \mathrm{O}$,
$6 \mathrm{mg}$ citric acid, $36 \mathrm{mg} \mathrm{CaCl} \cdot 2 \mathrm{H}_{2} \mathrm{O}, 75 \mathrm{mg} \mathrm{MgSO}_{4} \cdot 7 \mathrm{H}_{2} \mathrm{O}$, $40 \mathrm{mg} \mathrm{K} \mathrm{HPO}_{4} \cdot 3 \mathrm{H}_{2} \mathrm{O}, 20 \mathrm{mg} \mathrm{Na} \mathrm{CO}_{3}$ and $1 \mathrm{ml}$ of trace element solution A5 per liter. Solution A5 contained $2.86 \mathrm{gL}^{-1}$ $\mathrm{H}_{3} \mathrm{BO}_{3}, 1.81 \mathrm{gL}^{-1} \mathrm{MnCl}_{2} \cdot 4 \mathrm{H}_{2} \mathrm{O}, 0.222 \mathrm{gL}^{-1} \mathrm{ZnSO}_{4}, 0.079 \mathrm{gL}^{-1}$ $\mathrm{CuSO}_{4} \cdot 5 \mathrm{H}_{2} \mathrm{O}, \quad 0.05 \mathrm{gL}^{-1} \mathrm{CoCl}_{2} \cdot 6 \mathrm{H}_{2} \mathrm{O}$ and $0.391 \mathrm{gL}^{-1}$ $\mathrm{NaMoO}_{4} \cdot 2 \mathrm{H}_{2} \mathrm{O}$. Deionized distilled water (Milli-Q ${ }^{\circledR}, \mathrm{EMD}$ Millipore, Darmstadt, Germany) was used for the preparation of media, which were heat sterilized in an autoclave at $121^{\circ} \mathrm{C}$ and under 1 bar of overpressure for 20 minutes.

\subsection{Cultivations}

A comparative experiment of the three species was conducted in a 1 L bioreactor (Biostat $\mathrm{Q}^{\circledR}$, B. Braun Biotech International, Melsungen, Germany) with a working volume of $700 \mathrm{~mL}$, under alternating 16-hour illuminated and 8-hour dark cycles. The illuminance value was 900 lux, which was provided by a conventional $60 \mathrm{~W}$ bulb. Some fermentations were conducted in batch mode (see Table 1) and others in repeated-batch mode, which mean that after a cultivation time of 485 hours ca. $80 \%$ of the broth was removed and the same volume of fresh BG-11 medium added.

A pH electrode and a thermometer were installed in the fermenters. No adjustment of the $\mathrm{pH}$ was required because the $\mathrm{pH}$ values varied within a suitable range for growth (pH 6.5-9). Homogeneous mixing was assured by a magnetic stirrer. Aeration was varied according to Table 1. Fermentors were sterilized at $121^{\circ} \mathrm{C}$ for 20 minutes in an autoclave. The comparative experiments of three strains were run in parallel for 818 hours in three identical fermentors. Two samples were taken per day to monitor the fermentations.

Experiments were also conducted to study the effect of cultivation techniques on infrared spectra, besides in the shaking flasks of the aforementioned bioreactor

Table 1 The properties of experiments

\begin{tabular}{|c|c|c|c|c|c|c|}
\hline Strain & Notation & Conditions & $\begin{array}{l}\text { Volume } \\
\text { (mL) }\end{array}$ & $\begin{array}{l}\text { Aeration flow rate } \\
\qquad\left(\operatorname{minL}^{-1}\right)\end{array}$ & $\begin{array}{l}\mathrm{CO}_{2} \\
(\%)\end{array}$ & $\begin{array}{l}\text { Illumination } \\
\text { type }\end{array}$ \\
\hline \multirow{3}{*}{$\begin{array}{l}\text { Chlorella } \\
\text { vulgaris (Hamburg) }\end{array}$} & $\mathrm{H} 1$ & flask cultivation, batch & 200 & - & - & natural \\
\hline & $\mathrm{H} 2$ & bioreactor fermentations, repeated batch & 700 & 0.2 & - & bulb \\
\hline & $\mathrm{H} 3$ & bioreactor fermentations, repeated batch & 700 & 0.2 & - & bulb \\
\hline \multirow{7}{*}{$\begin{array}{l}\text { Chlorella } \\
\text { vulgaris (Tihany) }\end{array}$} & $\mathrm{T} 1$ & non-stirred aerated column reactor, batch & 150 & 0.2 & - & bulb \\
\hline & $\mathrm{T} 2$ & bioreactor fermentations, repeated batch & 700 & 0.2 & - & bulb \\
\hline & $\mathrm{T} 3$ & bioreactor fermentations, repeated batch & 700 & 0.2 & - & bulb \\
\hline & $\mathrm{T} 4$ & bioreactor fermentations, batch & 700 & 0.2 & - & bulb \\
\hline & $\mathrm{T} 5$ & bioreactor fermentations, batch & 700 & 0.2 & 1 & bulb \\
\hline & T6 & bioreactor fermentations, batch & 700 & 0.2 & 5 & bulb \\
\hline & $\mathrm{T} 7$ & bioreactor fermentations, batch & 700 & 0.6 & 5 & bulb \\
\hline Nannochloropsis sp. & N3 & bioreactor fermentations, batch & 700 & 0.2 & - & bulb \\
\hline
\end{tabular}


experiments (labelled as H1 in Table 1) and non-stirred aerated bubble column (labelled as T1 in Table 1). A summary of our experiments and sample markings is given in Table 1.

After $818 \mathrm{~h}$ (on the $34^{\text {th }}$ day), the culture of the isolate from Tihany was further tested with carbon-dioxide enrichment. Carbon dioxide was mixed into the airflow at a concentration of 1 and $5 \%$ whilst the rate of the airflow varied between 0.2 and $0.6 \mathrm{minL}^{-1}$ (Table 1).

\subsection{Sample preparations and measurements}

To follow the fermentations in the shaking flasks and different bioreactors, the optical density was measured by a spectrophotometer. A centrifuged (almost cell-free) supernatant, cell suspension, filtered fermentation broth (completely cell-free) and dried biomass were used for IR spectroscopy measurements from the fermented broth.

\subsubsection{Optical density}

Measurements of optical density (OD) were performed to monitor the course of the experiments by taking $1.5 \mathrm{ml}$ samples. The OD was measured by a spectrophotometer at $560 \mathrm{~nm}$ in a 3 -fold dilution in triplicates. Because the media only contained very small amounts of inorganic salts, distilled water was used as a blind reference.

\subsubsection{Fourier-transform infrared (FT-IR) spectroscopy} The cultured biomasses were tested by a FT-IR spectrometer with attenuated total reflection (ATR) technique. Different harvesting and cultivation types were compared based on IR spectra.

To elaborate on an appropriate method of measuring IR, 4 different sample preparation techniques were compared for all fermentations as follows: 1) the IR spectra of $100-100 \mathrm{ml}$ of the complete final fermentation broths (media+cells) were recorded, 2) the remaining fermentation broths were concentrated twenty-fold by centrifugation (5000rpm, $4^{\circ} \mathrm{C}, 20 \mathrm{~min}$., Janetzki K23D). The concentrated cell suspension was membrane-filtered $(0.2 \mathrm{~mm})$ and filter cakes were removed then vacuum-dried (130 mbar, $30^{\circ} \mathrm{C}$, Memmert vacuum oven VO200, Germany). The IR spectra of three dried samples were recorded from all fermentations: 2a) vacuum-dried biomass, 2 b) vacuum-dried biomass grinded in a mortar and 2c) the filter membrane that still contained the rest of the filter cake. For blank measurements, pure (empty) media were used. Three parallel measurements were made from each sample. According to previous experience, solid samples should be grinded because of the inhomogeneity and inertia of the ATR with the diamond/ZnSe composite crystal having been subjected to a large degree of variance in the parallel measurements. The IR spectrum was recorded at a resolution of $4 \mathrm{~cm}^{-1}$ in the $4000-650 \mathrm{~cm}^{-1}$ wavenumber range, but in aqueous samples only between 1500 and $1000 \mathrm{~cm}^{-1}$ and in solid ones between 1800 and $800 \mathrm{~cm}^{-1}$ were evaluated for both aqueous and solid samples. The main purposes of these wavenumber ranges were to avoid the water absorption bands resulting from IR absorption and highlight the so-called fingerprint range [32]. IR spectra were collected by a PerkinElmer Spotlight 400 FT-IR/FT-NIR spectrophotometer and its associated Universal Attenuated Total Reflection (UATR) sample treatment unit (PerkinElmer, Inc., Waltham, MA, USA) using a compressive force of 100 N. For the evaluation of IR spectra, Statistica 12.5 software (StatSoft, Inc., Tulsa, OK, USA) was used. For the analysis of IR spectra, the principal component analysis (PCA) and cluster analysis (CA) were selected from multivariate data analysis techniques [33].

\section{Results and Discussion}

The goal of our work was to examine the applicability of FT-IR in terms of the detection of differences in intracellular compositions originating from different cultivation methods and isolates.

A comprehensive fermentation experiment was conducted with three different microalgae strains (isolates of Chlorella vulgaris from Tihany and Hamburg in addition to Nannochloropsis sp.) in 3 parallel batch fermentations. Optical density data measured off-line are presented in Fig. 1. These fermentations not only provided biomasses for FT-IR investigations, but were also used to select the highest biomass-producing strain for further cultivation tests that apply different aeration rates and $\mathrm{CO}_{2}$ enrichment. According to Fig. 1 the fastest growth was exhibited by the isolate from Tihany which also produced the highest OD value that was also visible and exhibited the darkest green color (Fig. 2)

The final concentration of dry biomass achieved in the experiments correlates with the results of the OD measurements, i.e. Nannochloropsis sp.: $0.21 \mathrm{gL}^{-1}$, Chlorella vulgaris (Hamburg): $0.23 \mathrm{gL}^{-1}$, and Chlorella vulgaris (Tihany): $0.37 \mathrm{gL}^{-1}$ dry biomass yield.

Since water exhibits a dominant signal on IR spectra, dissolved and/or suspended aqueous material cannot be evaluated (data not shown). Therefore, only information-rich spectral fragments $\left(1800-800 \mathrm{~cm}^{-1}\right)$ of dried solid samples are presented (Fig. 3). 


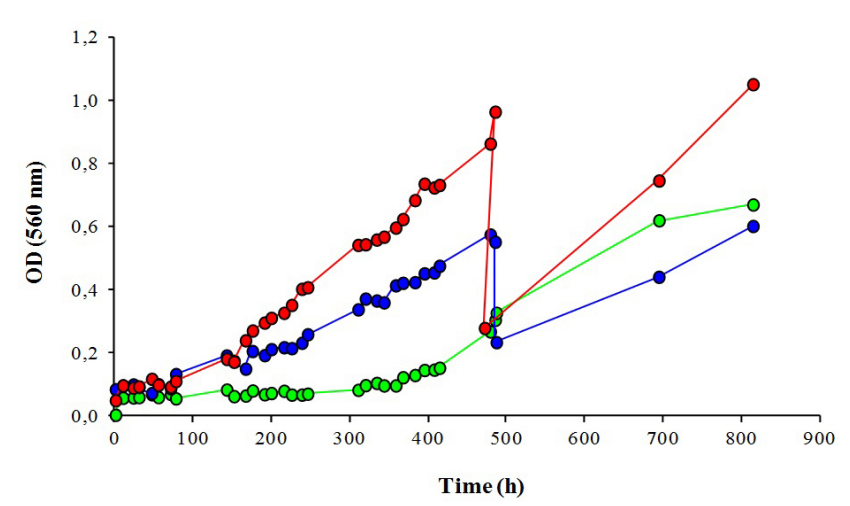

Fig. 1 OD results of parallel fermentations: Nannochloropsis $s p$. (N3) $\bullet$, Chlorella vulgaris (Tihany) (T3) $\bullet$, Chlorella vulgaris (Hamburg) (H3)

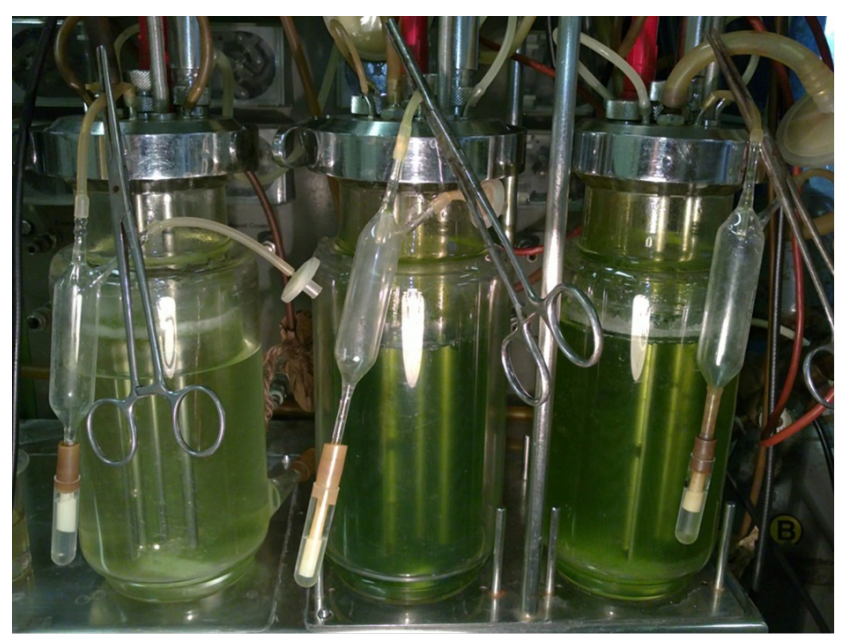

Fig. 2 Fermentations in bioreactors: Nannochloropsis sp. (N3, left), Chlorella vulgaris (Tihany) (T3, middle), Chlorella vulgaris (Hamburg) (H3, right)

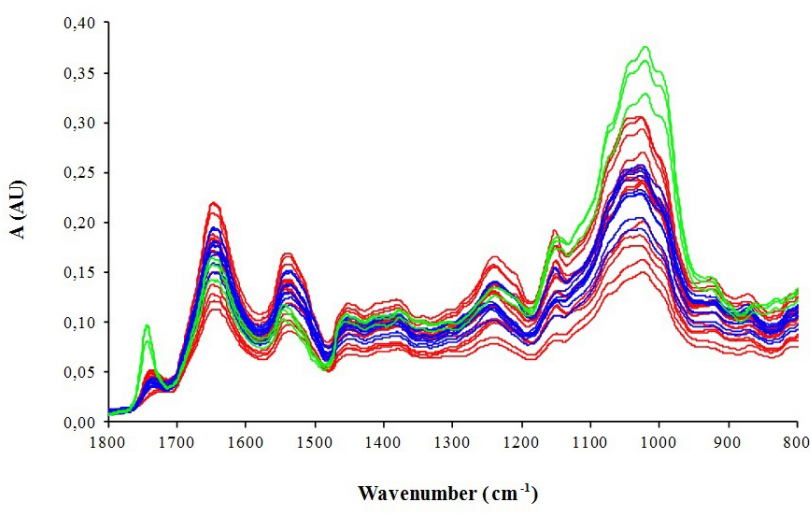

Fig. 3 FT-IR spectra in the range of $1800-800 \mathrm{~cm}^{-1}$ wavenumbers Nannochloropsis $s p .(\mathrm{N} 3)-$, Chlorella vulgaris (Tihany, T1-T7) Chlorella vulgaris (Hamburg, H1-H3) -

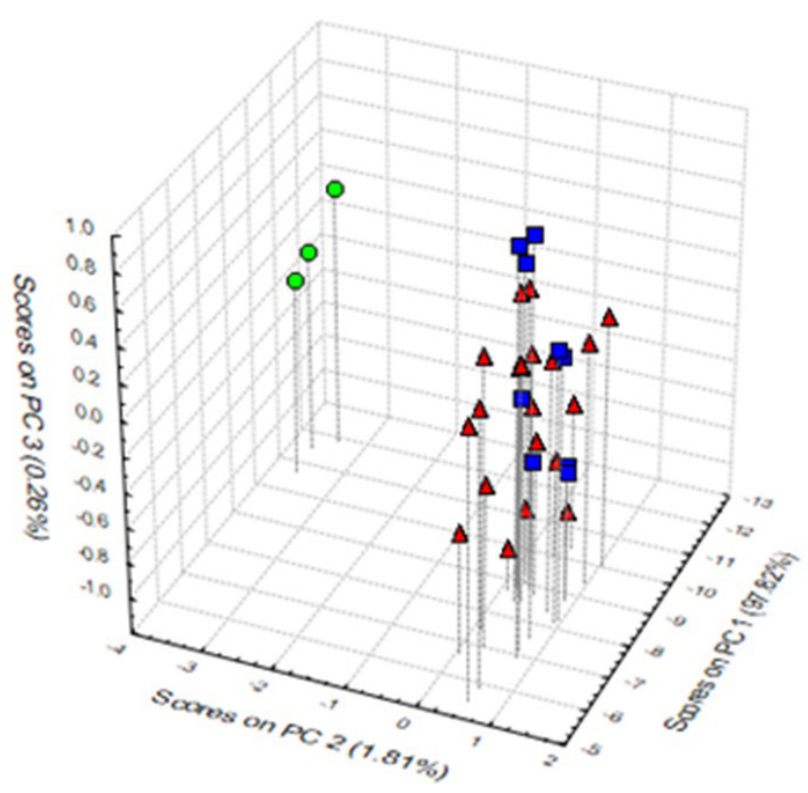

Fig. 4 The complete FT-IR spectra of the sample group. The first three score plots of principal components (PC1-3) of the PCA in the range of 1800-800 cm-1 wavenumbers: Nannochloropsis sp. (N3) O, Chlorella vulgaris (Tihany, T1-T7) $\boldsymbol{\Delta}$, Chlorella vulgaris (Hamburg, H1-H3)

In the examined region, the spectroscopic differences between the two genera can be seen even before multivariate data analysis: for example, at $1740 \mathrm{~cm}^{-1}$, the spectra of the Nannochloropsis species exhibit sharply separated peaks (black arrow on Fig. 3). Many articles reported that this absorption range is correlated with lipids. [7-8, 33-34]. The analysis of the IR spectra using PCA followed by the illustration of its output, so-called score values, shows clear differences between the species (Fig. 4). In the case of IR spectra, the first three principal components (PCs) usually describe almost $100 \%$ of spectroscopic variability, subsequently the first three major components were examined. In terms of the second principal component (PC2), the sample group of Nannochloropsis separates sharply.

The weight function of PC2 (Fig. 5) shows characteristic peaks at four typical absorption bands which are denoted by black arrows in Fig. 5 (around 1740, 1645, 1530 and $980 \mathrm{~cm}^{-1}$ ).

These peaks can be linked to specific vibrations of lipids, proteins and carbohydrates [7-8, 32-34] (Table 2).

The peak height of these absorption bands was determined as the relative amount of each major chemical component of green algae, i.e. lipids, proteins and carbohydrates, which are nutritional key components in each experiment (Fig. 6). 
Table 2 Summary of the vibration of specific groups according to their

\begin{tabular}{lc}
\multicolumn{2}{c}{ wavenumbers } \\
\hline Wavenumber & Group vibration \\
\hline$\sim 1740 \mathrm{~cm}^{-1}$ & $v \mathrm{C}=\mathrm{O}$ ester group vibration \\
lipids and fatty acids \\
$\sim \mathrm{C}=\mathrm{O}$ amide group vibration \\
proteins (amide I) \\
$\delta \mathrm{N}-\mathrm{H}$ amide group vibration \\
$\sim 1540 \mathrm{~cm}^{-1}$ & proteins (amide II) \\
& $v \mathrm{C}-\mathrm{O}-\mathrm{C}$ vibration \\
& carbohydrates \\
\hline $1200-900 \mathrm{~cm}^{-1}$ &
\end{tabular}

The nutritional profiles reflect well both the isolates, i.e. $\mathrm{N}, \mathrm{H}$ and $\mathrm{T}$, and the different culture conditions. The latter is well illustrated by the lower lipid content of the experiment in the bubble column reactor (T1), or the higher lipid content of the shake flask experiments (H1) with Chlorella vulgaris green algae from Hamburg (H series) (Fig. 6(a)). It should be noted that while the difference in lipid content between the isolates, i.e. $\mathrm{N}, \mathrm{H}$ and $\mathrm{T}$, is significant at a confidence level of $95 \%$ (Fig. 6(a)), the contents of
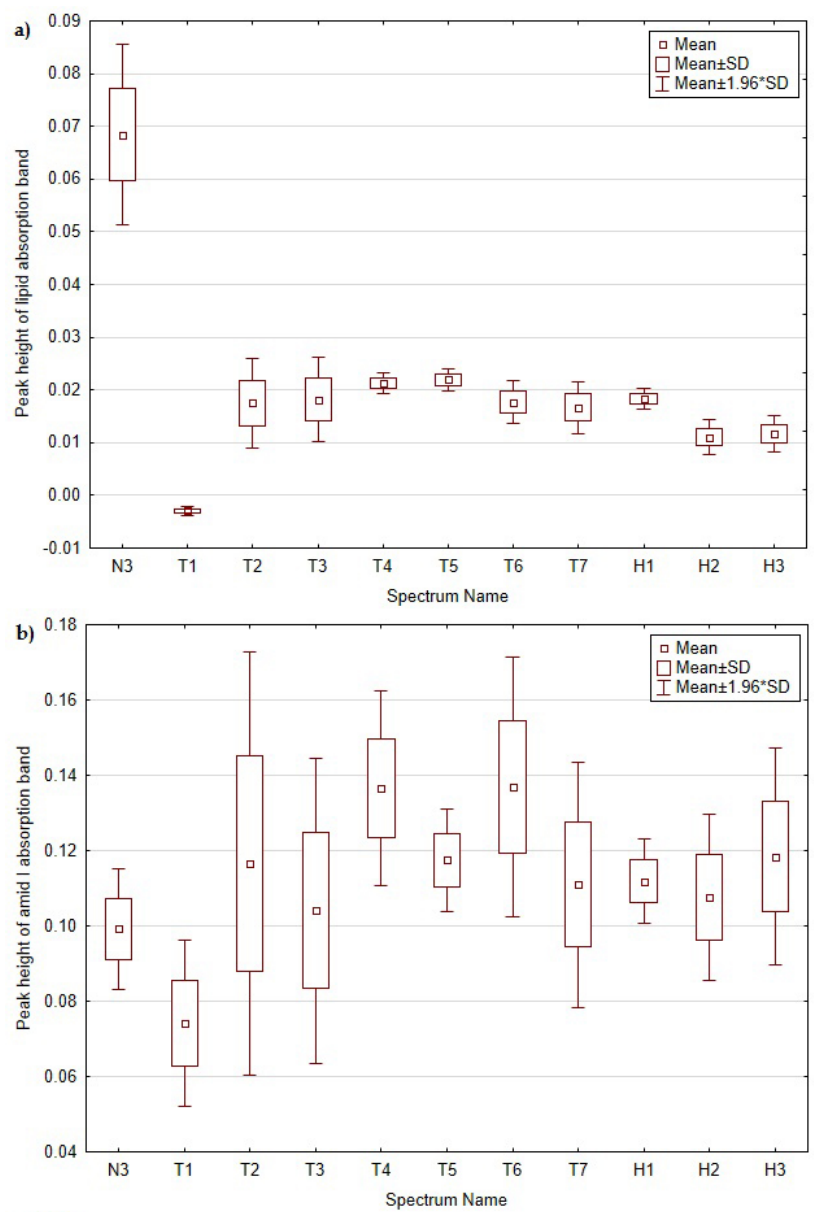

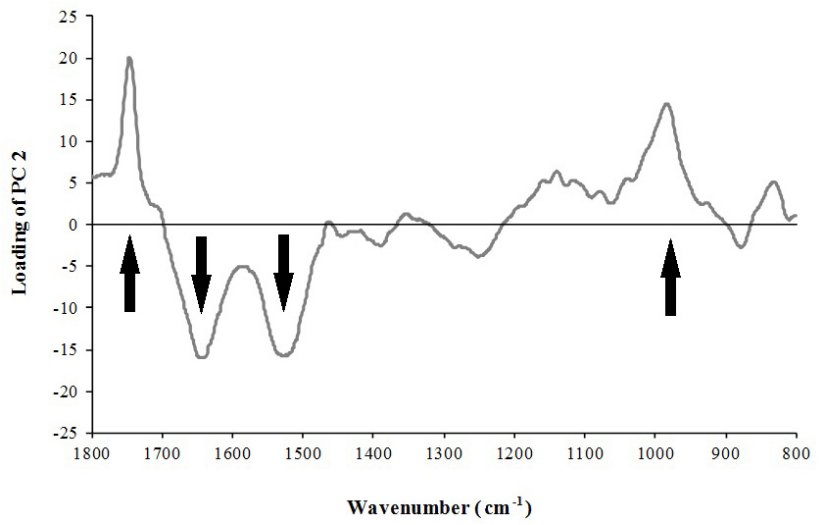

Fig. 5 Weight function of PC2 generated based of all recorded spectra between $1800-800 \mathrm{~cm}^{-1}$ wavenumbers.

protein and carbohydrate show only minor differences. However, different species and cultivations have resulted in diversity that can still be observed (Fig. 6(b)-(d)). The highest correlation coefficient (r), not surprisingly, is the protein content defined by the vibrations of amides I and II (0.97) during the complete cross-correlation of peak
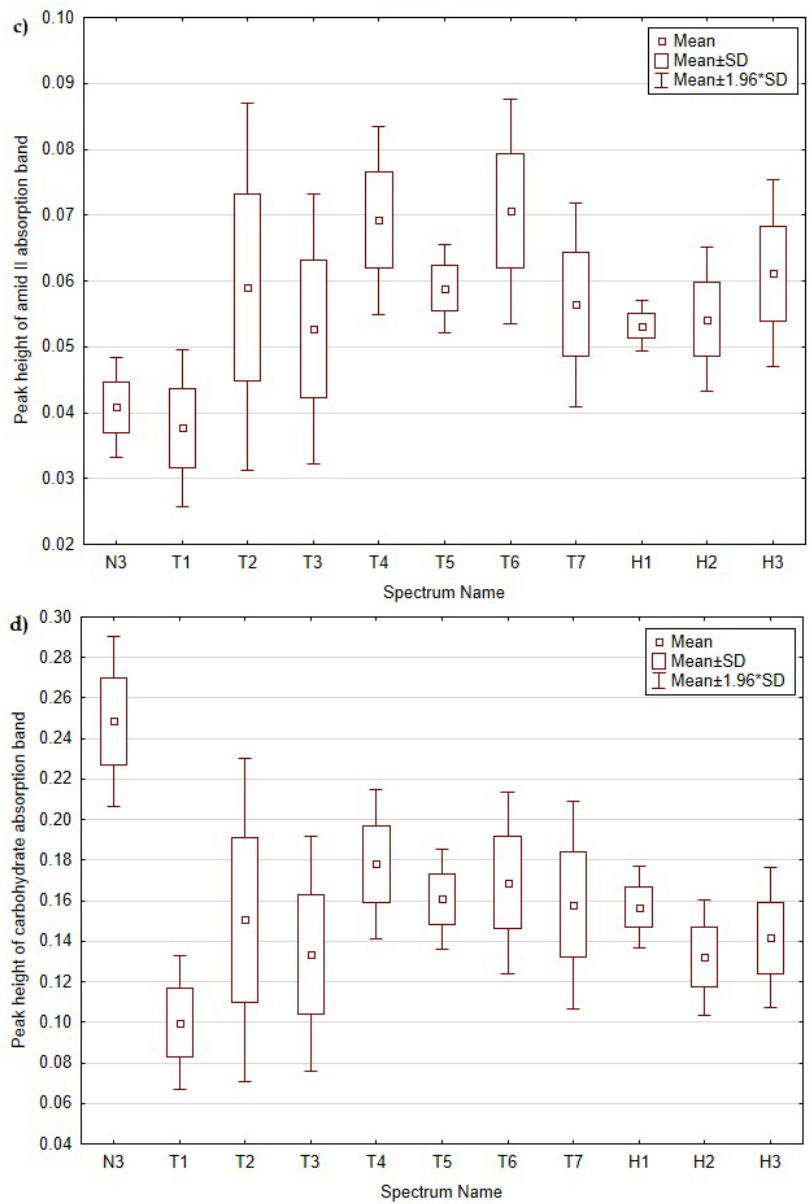

Fig. 6 The peak height of the lipid (a), protein (b-amide I, c-amide II) and carbohydrate (d) absorption bands of the FT-IR spectra of green algae cultivated in different experiments 
heights that reflect nutritional properties. Smaller, but still significant, $r$ values $(0.87)$ are shown by the correlation values of lipid and carbohydrate content.

Since the isolate of Chlorella vulgaris from Tihany exhibited the highest final OD, it was selected for further studies. In the following, only the relative position of the isolate from Tihany was studied in the PCA. It can be stated that the different types of cultivation are well separated, forming distinctive groups (Fig. 7).

The T1 samples (O) were extracted from the bubble column reactor. The other samples (T2-T4 $\Delta, \mathrm{T} 5 \square$, T6 $\rightarrow$ and $\mathrm{T} 7 *$ ) were cultured in the same Biostat bioreactor. The batches T2-T4, which were not subject to atmospheric change, are more distinct from samples that were exposed to different concentrations of $\mathrm{CO}_{2}$ by changing the aeration rate (T5-T7). The non-stirred aerated experiment (T1) is likely to be significantly separated due to the differences in content (Fig. 6) discussed earlier. This is confirmed by the weight function of PC1 (Fig. 8(a)), where high lipid, protein and carbohydrate absorption sites are obtained at high local extremes. The weight function for PC2 (Fig. 8(b)) yields the maximum extremes within the range of $12501100 \mathrm{~cm}^{-1}$ wavenumbers. Many reports have revealed that bicyclic monoterpenes $\left(\sim 1214 \mathrm{~cm}^{-1}, \mathrm{C}-\mathrm{O}-\mathrm{C}\right)$ and pectin $\left(\sim 1150 \mathrm{~cm}^{-1}, \mathrm{C}-\mathrm{O}-\mathrm{C}\right)$ exhibit absorption in this region based on vibrations of the $\mathrm{C}-\mathrm{O}-\mathrm{C}$ group, which can be associated with subunits of carbohydrate. Thus, the altered atmospheric composition affects the carbohydrate content of algae biomass [21, 26, 33-34].

\section{Conclusion}

Conclusions from the evaluation revealed that both the type of fermentation and the set of conditions affect the intracellular content of microalgae. Based on the FT-IR spectra, the greatest difference was observed in the varieties of lipids and carbohydrates. The results also demonstrated that the sensitivity of FT-IR spectroscopy is excellent for monitoring the cultivation of algae and fermentation conditions.

It was concluded that FT-IR spectroscopy is a fast, reliable and appropriate technique to detect qualitative differences in the compositions of microalgae. For a quantitative application of FT-IR spectroscopy, reference laboratory testing is necessary.

Therefore, with the help of the available FT-IR spectroscopic technique, appropriate reference laboratory tests, e.g. Soxhlet extraction and Dumas total nitrogen determination, and a sufficient amount of biomass it will be possible to create and validate quantitative calibration between

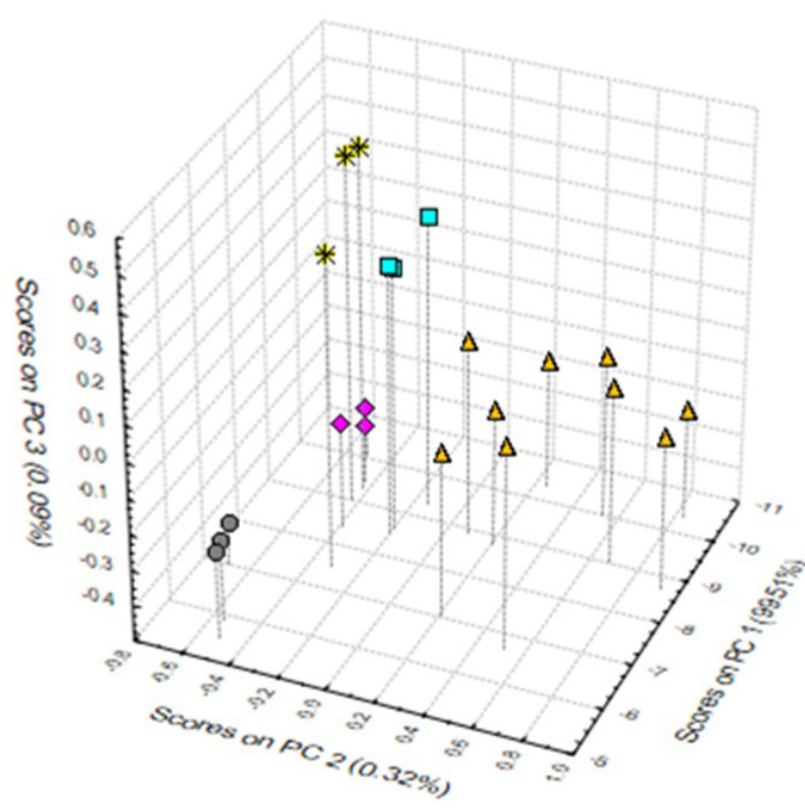

Fig. 7 Score plot of PCA from different spectra of Tihany isolate T1 $\mathrm{T} 2-\mathrm{T} 4 \Delta, \mathrm{T} 5 \backsim, \mathrm{T} 6 \bullet, \mathrm{T} 7$ *.
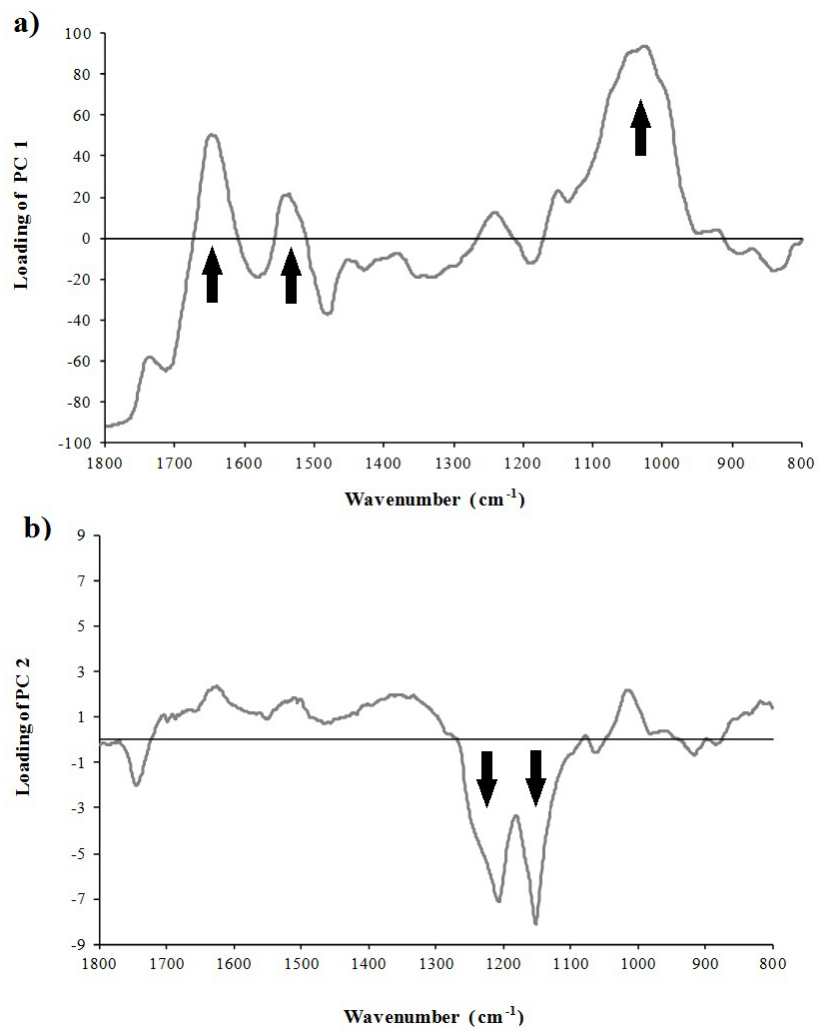

Fig. 8 Weight function of PCA : a) for PC1 and b) for PC2 in case of Tihanyi isolate within the range of $1800-800 \mathrm{~cm}^{-1}$ wavenumbers

reference data determined both by spectroscopy and a reference method. This will both speed up quantitative determination of the content of algae-based products and make the monitoring of fermentations more effective. 


\section{References}

[1] Chisti, Y. "Biodiesel from microalgae", Biotechnology Advances, 25(3), pp. 294-306, 2007.

https://doi.org/10.1016/j.biotechadv.2007.02.001

[2] Milano, J., Ong, H. C., Masjuki, H. H., Chong, W. T., Lam, M. K., Loh, P. K., Vellayan, V. "Microalgae biofuels as an alternative to fossil fuel for power generation", Renewable and Sustainable Energy Reviews, 58, pp. 180-197, 2016.

https://doi.org/10.1016/j.rser.2015.12.150

[3] Spolaore, P., Joannis-Cassan, C., Duran, E., Isambert, A. "Commercial applications of microalgae", Journal of Bioscience and Bioengineering, 101(2), pp. 87-96, 2006.

https://doi.org/10.1263/jbb.101.87

[4] Karemore, A., Sen, R. "Downstream processing of microalgal feedstock for lipid and carbohydrate in a biorefinery concept: a holistic approach for biofuel applications", RSC Advances, 6(35), pp. 29486-29496.

http://doi.org/10.1039/C6RA01477A

[5] Baicha, Z., Salar-García, M. J., Ortiz-Martínez, V. M., HernándezFernández, F. J., de los Ríos, A. P., Labjar, N., Lotfi, E., Elmahi, M. "A critical review on microalgae as an alternative source for bioenergy production: A promising low cost substrate for microbial fuel cells", Fuel Processing Technology, 154, pp. 104-116, 2016.

https://doi.org/10.1016/j.fuproc.2016.08.017

[6] Imhoff, J. F., Labes, A., Wiese, J. "Bio-mining the microbial treasures of the ocean: New natural products", Biotechnology Advances, 29(5), pp. 468-482, 2011.

https://doi.org/10.1016/j.biotechadv.2011.03.001

[7] Benemann, J. R., Weissman, J. C., Koopman, B. L., Oswald, W. J. "Energy production by microbial photosynthesis", Nature, 268, pp. 19-23, 1977.

https://doi.org/10.1038/268019a0

[8] Meng, Y., Yao, C., Xue, S., Yang, H. "Application of Fourier transform infrared (FT-IR) spectroscopy in determination of microalgal compositions", Bioresource Technology, 151, pp. 347-354, 2014. https://doi.org/10.1016/j.biortech.2013.10.064

[9] Vanthoor-Koopmans, M., Wijffels, R. H., Barbosa, M. J., Eppink, M. H. M. "Biorefinery of microalgae for food and fuel", Bioresource Technology, 135, pp. 142-149, 2013.

https://doi.org/10.1016/j.biortech.2012.10.135

[10] Plaza, M., Cifuentes, A., Ibáñez, E. "In the search of new functional food ingredients from algae", Trends in Food Science \& Technology, 19(1), pp. 31-39, 2008. https://doi.org/10.1016/j.tifs.2007.07.012

[11] Villarruel-López, A., Ascencio, F., Nuño, K. "Microalgae, a Potential Natural Functional Food Source - a Review", Polish Journal of Food and Nutrition Sciences, 67(4), pp. 251-263, 2017. https://doi.org/10.1515/pjfns-2017-0017

[12] Luo, X., Su, P., Zhang, W. "Advances in Microalgae-Derived Phytosterols for Functional Food and Pharmaceutical Applications", Marine Drugs, 13(7), pp. 4231-4254, 2015. https://doi.org/10.3390/md13074231

[13] Wang, H.-M. D., Chen, C.-C., Huynh, P., Chang, J.-S. "Exploring the potential of using algae in cosmetics", Bioresource Technology, 184, pp. 355-362, 2015.

https://doi.org/10.1016/j.biortech.2014.12.001
[14] Ariede, M. B., Candido, T. M., Jacome, A. L. M., Velasco, M. V. R., de Carvalho, J. C. M., Baby, A. R. "Cosmetic attributes of algae - A review", Algal Research, 25, pp. 483-487, 2017.

https://doi.org/10.1016/j.algal.2017.05.019

[15] Shanab, S. M. M., Mostafa, S. S. M., Shalaby, E. A., Mahmoud, G. I. "Aqueous extracts of microalgae exhibit antioxidant and anticancer activities", 2(8), pp. 608-615, 2012. https://oi.org/10.1016/S2221-1691(12)60106-3

[16] Siddiqui, M. W., Prasad, K. "Plant Secondary Metabolites, Volume One: Biological and Therapeutic Significance", 1st ed., Apple Academic Press, OAkville, On, USA, 2017.

[17] Tang, G., Suter, P. M. "Vitamin A, Nutrition, and Health Values of Algae: Spirulina, Chlorella, and Dunaliella", Journal of Pharmacy and Nutrition Sciences, 1(2), pp. 111-118, 2011. https://doi.org/10.6000/1927-5951.2011.01.02.04

[18] Safafar, H., van Wagenen, J., Møller, P., Jacobsen, C. "Carotenoids, Phenolic Compounds and Tocopherols Contribute to the Antioxidative Properties of Some Microalgae Species Grown on Industrial Wastewater", Marine Drugs, 13(12), pp. 7339-7356, 2015. https://doi.org/10.3390/md13127069

[19] Vo, T.-S., Ngo, D.-H., Kim, S.-K. "Marine algae as a potential pharmaceutical source for anti-allergic therapeutics", Process Biochemistry, 47(3), pp. 386-394, 2012. https://doi.org/10.1016/j.procbio.2011.12.014

[20] Víg, R., Dobos, A., Molnár, K., Nagy, J. "Természetes alapú lombtrágyák hatékonysága szabadföldi kísérletekben: I. Kukorica (Zea mays L.)" (The efficiency of natural foliar fertilisers in field experiments: I. Maize (Zea mays L.), Növénytermelés, 59(4), pp. 89-105, 2010. (in Hungarian) https://doi.org/10.1556/Novenyterm.59.2010.4.6

[21] Dalmadi, I., Seregély, Zs., Kaffka, K., Farkas, J. "Élelmiszervizsgálati Közlemények" (Food Probative Publications), Vol. 53, pp. 222-238, 2007. (in Hungarian)

[22] Gressler, V., Yokoya, N. S., Fujii, M. T., Colepicolo, P., Filho, J. M., Torres, R. P., Pinto, E. "Lipid, fatty acid, protein, amino acid and ash contents in four Brazilian red algae species", Food Chemistry, 120(2), pp. 585-590, 2010.

https://doi.org/10.1016/j.foodchem.2009.10.028

[23] Begum, H., Yusoff, F. M. D., Banerjee, S., Khatoon, H., Shariff, M. "Availability and Utilization of Pigments from Microalgae", Critical Reviews in Food Science and Nutrition, 56(13), pp. 22092222, 2016. https://doi.org/10.1080/10408398.2013.764841

[24] Zhou, Q., Zhang, P., Zhang, G., Peng, M. "Biomass and pigments production in photosynthetic bacteria wastewater treatment: Effects of photoperiod", Bioresource Technology, 190, pp. 196-200, 2015. https://doi.org/10.1016/j.biortech.2015.04.092

[25] El Gamal, A. A. " Biological importance of marine algae", Saudi Pharmaceutical Journal, 18(1), pp. 1-25, 2012. https://doi.org/10.1016/j.jsps.2009.12.00

[26] Chini Zittelli, G., Lavista, F., Bastianini, A., Rodolfi, L., Vincenzini, M., Tredici, M. R. "Production of eicosapentaenoic acid by Nannochloropsis sp. cultures in outdoor tubular photobioreactors", Journal of Biotechnology, 70(1-3), pp. 299-312, 1999. https://doi.org/10.1016/S0168-1656(99)00082-6 
[27] Chen, C.-Y., Jesisca, Hsieh, C., Lee, D.-J., Chang, C.-H., Chang, J.-S. "Production, extraction and stabilization of lutein from microalga Chlorella sorokiniana MB-1", Bioresource Technology, 200, pp. 500-505, 2016. https://doi.org/10.1016/j.biortech.2015.10.071

[28] Ursu, A.-V., Marcati, A., Sayd, T., Sante-Lhoutellier, V., Djelveh, G., Michaud, P. "Extraction, fractionation and functional properties of proteins from the microalgae Chlorella vulgaris", Bioresource Technology, 157, pp. 134-139, 2014. https://doi.org/10.1016/j.biortech.2014.01.071

[29] Harun, R., Singh, M., Forde, G. M., Danquah, M. K. "Bioprocess engineering of microalgae to produce a variety of consumer products", Renewable and Sustainable Energy Reviews, 14(3), pp. 1037-1047, 2010. https://doi.org/10.1016/j.rser.2009.11.004

[30] Nwoba, E. G., Ayre, J. M., Moheimani, N. R., Ubi, B. E., Ogbonna, J. C. "Growth comparison of microalgae in tubular photobioreactor and open pond for treating anaerobic digestion piggery effluent", Algal Research, 17, pp. 268-276, 2016. https://doi.org/10.1016/j.algal.2016.05.022
[31] Lee, T. H., Chang, J. S., Wang, H.-Y. "Rapid and in Vivo Quantification of Cellular Lipids in Chlorella vulgaris Using Near-Infrared Raman Spectrometry", Analytical Chemistry, 85(4), pp. 2155-2160, 2013. https://doi.org/10.1021/ac3028118

[32] Stanier, R. Y., Kunisawa, R., Mandel, M., Cohen-Bazire, G. "Purification and properties of unicellular blue-green algae (order Chroococcales)", Bacteriology Reviews, 35(2), pp. 171-205, 1971.

[33] Dean, A. P., Sigee, D. C., Estrada, B., Pittman, J. K. "Using FTIR spectroscopy for rapid determination of lipid accumulation in response to nitrogen limitation in freshwater microalgae", Bioresource Technology, 101(12), pp. 4499-4507, 2010. https://doi.org/10.1016/j.biortech.2010.01.065

[34] Coates, J. "Interpretation of Infrared Spectra, A Practical Approach", In: Encyclopedia of Analytical Chemistry, John Wiley \& Sons Ltd., Chichester, 2000, pp. 10815-10837. https://doi.org/10.1002/9780470027318.a5606 